Arq. Bras. Med. Vet. Zootec., v.66, n.3, p.763-768, 2014

\title{
Analysis of EGFR and HER-2 expressions in ductal carcinomas in situ in canine mammary glands
}

\author{
[Análise da expressão de EGFR e HER-2 em carcinomas ductais in situ \\ da glândula mamária canina]
}

I.L.D. Silva, A.P.M. Dias, A.C. Bertagnolli, G.D. Cassali, E. Ferreira*

Instituto de Ciências Biológicas - Universidade Federal de Minas Gerais - Belo Horizonte, MG

\begin{abstract}
Biomolecular evidence has shown that ductal carcinoma in situ (DCIS) may develop into invasive carcinoma of the canine mammary gland, and mutations in proto-oncogenes HER2 and EGFR; two members of the family of epidermal growth factor receptors, may be involved in this process. The purpose of this study was the characterization of the immunohistochemical expression of the EGFR and HER2 proteins in the process of neoplastic transformation, supposedly present in ductal carcinomas in situ in canine mammary glands. Fifteen cases of DCIS were evaluated, with a higher expression of HER2 and EGFR being observed in low-grade carcinomas when compared with high-grade neoplasms, and with a high positive statistical correlation in the latter. Results suggest that aggressive tumors tend to lose the expression of EGFR and HER2 simultaneously. The loss of the expression of these markers may be related to the process of neoplastic progression in canine mammary tumors.
\end{abstract}

Keywords: dog, neoplasm, immunohistochemistry, EGFR, CerbB2

\section{RESUMO}

Evidências biomoleculares sugerem que o carcinoma ductal in situ (CDIS) pode progredir para carcinoma invasor na mama canina e que mutações nos proto-oncogenes HER-2 e EGFR, dois membros da família de receptores para fatores de crescimento epidérmicos, podem estar envolvidas neste processo. A partir disso, este trabalho teve por objetivo caracterizar a expressão imuno-histoquímica das proteínas EGFR e HER-2 no processo de transformação neoplásica supostamente presente em carcinomas ductais in situ da glândula mamária canina. Foram avaliados 15 casos de CDIS, sendo observada maior expressão de HER-2 e EGFR em carcinomas de baixo grau em comparação às neoplasias de alto grau, com correlação estatística positiva alta nestes últimos. Os resultados sugerem que tumores mais agressivos tendem a perder, simultaneamente, a expressão de EGFR e HER-2. A perda na expressão desses marcadores pode estar envolvida no processo de progressão neoplásica em tumores mamários caninos.

Palavras-chaves: cão, neoplasia, imuno-histoquímica, EGFR, CerbB-2

\section{INTRODUCTION}

Studies have shown that several non-neoplastic mammary intraepithelial lesions have been associated with the development of invasive mammary carcinomas. Intraepithelial lesions known for being precursors to mammary cancer are atypical hyperplasias, changes in atypical columnar cells and carcinomas in situ (Krogerus et al., 2000; Dabbs et al., 2006). Ductal carcinoma in situ (DCIS) is characterized by a

Recebido em 31 de agosto de 2012

Aceito em 20 de dezembro de 2013

*Autor para correspondência (corresponding author)

E-mail: enioferreira@icb.ufmg.br proliferation of the malignant epithelial cells of the mammary ducts which tend to fill the ductal lumen, without disrupting the ductal basal membrane (Leonard and Swain, 2004). In humans, about half of local recurrence cases, after the treatment of DCIS, are diagnosed as invasive mammary carcinoma (Warnberg et al., 2001).

Similar to pre-neoplastic lesions found in humans, in situ carcinomas represent stages of neoplastic transformation in canine mammary 
cancer (Antuofermo et al., 2007; Ferreira et al., 2010). However, a careful morphological evaluation of these lesions and their molecular behavior has not been fully explored, preventing conclusive studies of the oncogenic behavior of these lesions (Antuofermo et al., 2007).

Mutations in proto-oncogenes such as HER2 and EGFR, two members of the family of epidermal growth factor receptors, are among the main genetic changes related to the development of human cancer. The importance of these receptors has been extensively studied in human mammary neoplasms even originating treatment specific to inhibit its activity (Slamon et al., 1987; Tsutusui et al., 2002; Yaziji et al., 2004; Owens et al., 2004; Bhargava et al., 2005).

The prognostic significance of the family of epidermal growth factor receptors in canine mammary tumors is still controversial. HER-2 and EGFR overexpression was associated with malignancy in canine mammary tumors. However, in other studies no correlation between HER-2 expression and survival was found (Gama et al., 2008; Gama et al., 2009; Bertagnolli et al., 2011). Furthermore, HER-2 protein overexpression has been detected in human breast cancer and is associated with resistance to different types of chemotherapeutic agents (Vogel et al., 2002). Therefore, a better histomorphological, immunophenotypical and behavioral characterization of DCIS will enable more appropriate treatments for these lesions.

The purpose of this study is to characterize the immunohistochemical expression of EGFR and HER2 in DCIS in canine mammary glands, with the aim to understand the role of DCIS in neoplastic progression.

\section{MATERIALS AND METHODS}

Fifteen cases of DCIS were obtained from samples obtained from clinical diagnosis and surgical removal of mammary tumors of pure and mixed breeds of dogs, performed at the "Hospital Veterinário", "Escola de Veterinária", UFMG. The cases had been diagnosed at the "Laboratório de Patologia Comparada", "Instituto de Ciências Biológicas", UFMG. Before inclusion in the study each case was reviewed and selected. Sample selection was based on the histological preservation of the tissue and on the associated occurrence of invasive carcinomas and ductal carcinomas in situ.

Lesions were classified as DCIS when they presented epithelial proliferations in intralobular or extralobular mammary ducts, involved more than two ductal units in the same histological section, had an atypical cell architecture, formed communicating bridges in the ductal lumen, and were delimited by a continuous layer of myoepithelial cells. The DCIS were divided in low-grade and high-grade lesions, using criteria such as increased cell atypia (mainly nuclear) and the loss of luminal cell polarization (Rosen, 2009).

Histological sections of $3 \mu \mathrm{m}$ of the selected samples were processed by the routine method of deparaffinization in xylene and rehydration of the material in a decreasing series of alcohol, followed by antigen retrieval in humid heat $\left(98^{\circ} \mathrm{C}\right)$, with citrate buffer solution $\mathrm{pH} 6.0$ (DakoCytomation Target Retrieval Solution) during 20 minutes. Afterwards, endogenous peroxidase was blocked in $\mathrm{H} 202$ solution at $3 \%$ in methyl alcohol.

In the immunohistochemical procedure, the technique of biotin-peroxidase development was carried out with identification from the polymerized secondary antibody (ADVANCE HRP - ready to use - DakoCytomation). Reagents were applied with the manual technique, with the time of incubation of primary antibody of 1 hour, HER2 (A0485; Dako; dilution: 1:40) and EGFR (clone 31G7; Zymed; dilution: 1:100). The other reagents had an incubation time of 30 minutes, except for DAB chromogen (DAB substrate system, Dakocytomation), and were incubated for five minutes. Samples of canine mammary gland previously tested were used as positive controls and negative controls were obtained by substituting primary antibody with normal serum.

The expression of EGFR and HER2 was evaluated according to the classification recommended by the American Society of Clinical Oncology/College of American Pathologists (ASCO/CAP) (Wolff et al., 2007), considering: $3+$ when over $30 \%$ of tumor cells have a uniform and intense membrane labeling; 
$2+$ when over $30 \%$ of cells have a non-uniform membrane labeling or over $10 \%$ of cells having a uniform membrane labeling; $1+$ when less than $10 \%$ of tumor cells have an incomplete membrane labeling; and 0 when no cell was labeled. Labeling is considered positive when the result was over $3+$.

Means of expression of EGRF and HER2 markers were compared using the statistical software GraphPad InStat v. 3.0 and with the use of the Mann-Whitney test. The frequency of marker expression was analyzed with the use of Fisher's exact test, with a significance level of $\mathrm{P}<0.05$.

All experimental procedures were carried out in accordance with the recommendations and the approval of the ethics committee animal experimentation of "Universidade Federal de Minas Gerais”, under protocol number 192/2006.

\section{RESULTS}

Six cases of low-grade CDIS were classified, when the cell pattern was predominantly monomorphic with no increase in nuclear size, a thin and diffuse chromatin and little prominent nucleoli and rare presence of mitotic figures. Nine cases diagnosed as high-grade DCIS were determined when we observed cells with high pleomorphism, a nuclear diameter twice as large as a normal ductal cell, loose or vesicular chromatin, prominent or multiple nucleoli, and a larger number of mitotic figures, when compared with low-grade DCIS. All 15 cases analyzed had an associated invasive mammary carcinoma (Fig. $1 \mathrm{~A}$ and $1 \mathrm{~B})$.

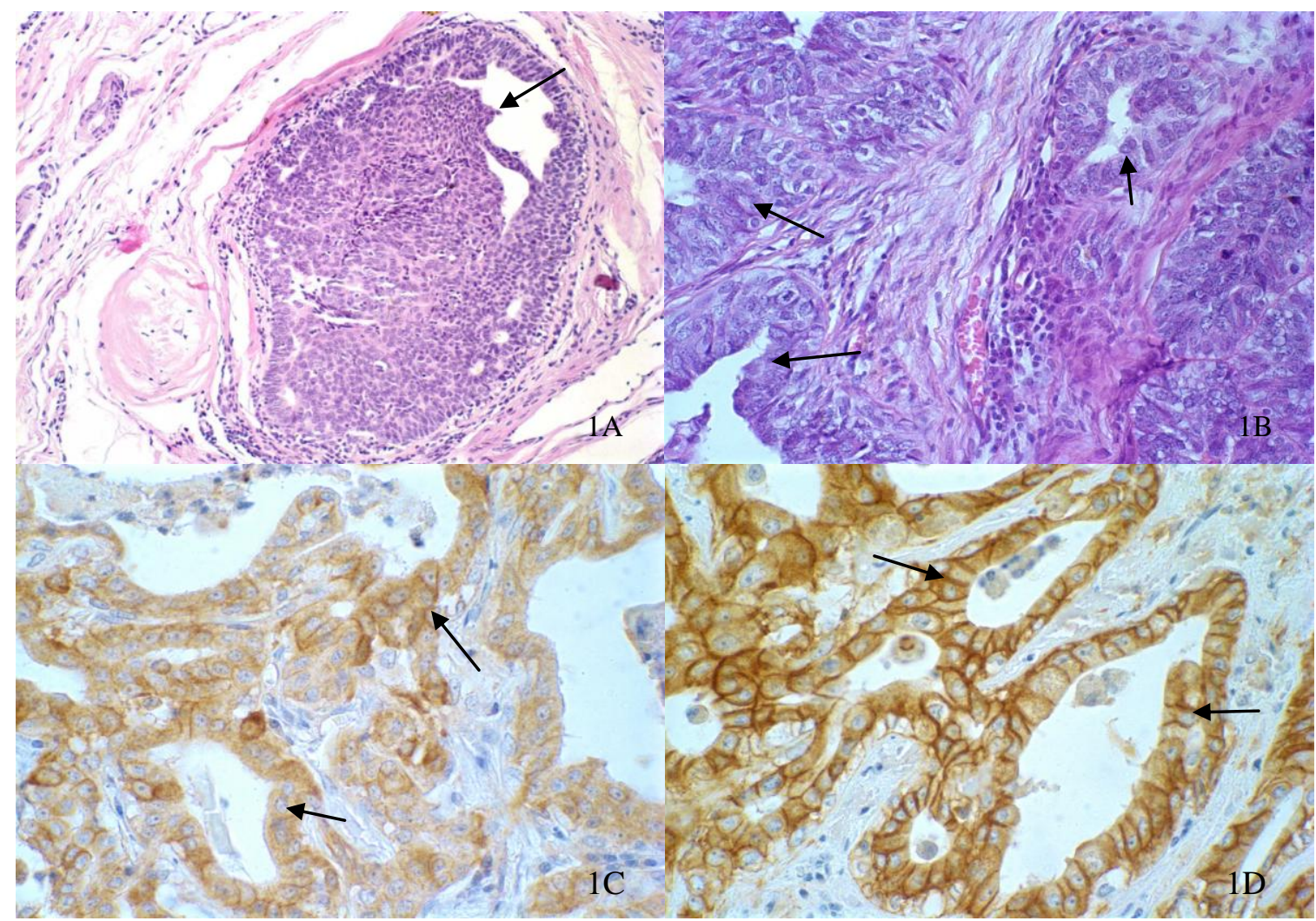

Figure 1 Canine mammary gland - (1A - 40X) Low grade carcinoma in situ: intraductal epithelial proliferation, with monomorphic cell pattern, with no increase in nuclear size, and diffuse fine chromatin, low nucleolar prominence, bound by a thin layer of myoepithelial cells (arrow). (1B - 40x) - High grade carcinoma in situ: intraductal epithelial proliferation, characterized by multiple layers of cells with high pleomorphism, bound by a thin layer of myoepithelial cells (arrow). (1C - 60X) - Low grade ductal carcinoma in situ showing strong membrane labeling of HER2 in more than $30 \%$ of the cells (3+) (arrow). (1D - 60X) - Low grade ductal carcinoma in situ showing strong membrane labeling of EGFR in more than $30 \%$ of the cells $(3+)$ (arrow). 
In the analysis of HER 2 expression of 15 cases, 8 $(53.3 \%)$ had a positive result $(+++)$ and 7 $(46.7 \%)$ had a negative result, with: $4(26.6 \%)$ $(++), 1(6.6 \%)(+)$ and $2(13.3 \%)$ not presenting membrane labeling. Low-grade DCIS had a higher mean of expression $(2.67 \pm 0.52)$ when compared with high-grade tumors $(1.89 \pm 1.27)$ $(\mathrm{p}=0.05)$, thus showing a tendency of a loss of HER2 expression in high-grade DCIS.

In the analysis of EGFR expression, of 15 cases, $4(26.6 \%)$ had a positive result (+++) and 11 (73.4\%) had a negative result, with: $3(20.0 \%)$ $(++), 5(33.3 \%)(+)$ and $3(20.0 \%)$ with no membrane labeling. Similar to the means of HER2 expression, the mean of EGFR expression in low-grade DCIS was lower $(1.67 \pm 1.21)$ when compared to high-grade tumors $(1.44 \pm 1.13)$ (Fig. 1C and 1D). That shows the existence of a loss of EGFR expression in more aggressive tumors, but with no statistical difference $(\mathrm{p}=0.72)$.

A positive and a negative labeling were observed for both markers (3 positive and 6 negative cases). Interestingly, when analyzing the correlation between the expression of markers, a strong positive correlation was identified in high-grade carcinomas $(r=0.82$; $\mathrm{p}<0.05)$. In the frequency analysis, no statistical differences were found between HER2 or EGFR expression in low-grade and high-grade DCIS. Results obtained from the immunohistochemical expression analysis of EGFR and HER2 are shown in Tables 1, 2 and 3.

Table 1. Correlation between the expression of HER-2 and EGFR and histological grade in ductal carcinomas in situ

\begin{tabular}{cccc}
\hline Case & HG & EGFR $^{\text {a }}$ & HER2 $^{\text {a }}$ \\
\hline 1 & Low & 3 & 2 \\
2 & Low & 3 & 3 \\
3 & Low & 1 & 2 \\
4 & Low & 0 & 3 \\
5 & Low & 1 & 3 \\
6 & Low & 2 & 3 \\
7 & High & 2 & 3 \\
8 & High & 3 & 3 \\
9 & High & 0 & 0 \\
10 & High & 1 & 1 \\
11 & High & 3 & 3 \\
12 & High & 1 & 3 \\
13 & High & 1 & 2 \\
14 & High & 2 & 2 \\
15 & High & 0 & 0 \\
\hline Average & & 1,53 & 2,20 \\
\hline SD & & 1,12 & 1,08
\end{tabular}

HG: Histological grade, EGFR: epidermal growth factor receptor, HER2: human epidermal growth factor receptor, SD: Standard deviation

a ' 0 ', no staining; '+', weak, incomplete membrane staining of any proportion of tumour cells; ' ++ ', complete membrane staining that is either non-uniform or weak in intensity, but with obvious circumferential distribution in $\geq 10 \%$ of cells, or intense, complete membrane staining of $<30 \%$ of tumour cells; ' +++ ', uniform, intense membrane staining of $>30 \%$ of tumour cells.

Table 2. Frequency of positivity for HER -2 in high-grade and low grade ductal carcinoma in situ (+) Labeling is considered positive when the result is over 3+

\begin{tabular}{lllr}
\hline & High grade CDIS & Low grade CDIS & Total \\
\hline HER-2 (+) & $4(26,7 \%)$ & $4(26,7 \%)$ & $8(53,4 \%)$ \\
HER-2 (-) & $5(33,3 \%)$ & $2(13,3 \%)$ & $7(46,6 \%)$ \\
\hline Total & $9(60 \%)$ & $6(40 \%)$ & $15(100 \%)$ \\
\hline
\end{tabular}

Table 3. Frequency of positivity for EGFR in high-grade and low grade ductal carcinoma in situ (+) Labeling is considered positive when the result is over $3+$

\begin{tabular}{lllr}
\hline & High grade CDIS & Low grade CDIS & Total \\
\hline EGFR (+) & $2(13,3 \%)$ & $2(13,3 \%)$ & $4(26,6 \%)$ \\
EGFR (-) & $7(46,7 \%)$ & $4(26,7 \%)$ & $11(73,4 \%)$ \\
\hline Total & $9(60 \%)$ & $6(40 \%)$ & $15(100 \%)$ \\
\hline
\end{tabular}

\section{DISCUSSION}

The profile of HER2 expression is used as an important prognostic and predictive tool (Dabss et al., 2006). According to Stoll (1999), the increase in HER2 expression is directly related to the increase in the malignancy character of mammary carcinomas. 
In dogs, mammary carcinomas phenotypically classified as luminal B (RE+/HER2+) or with HER2 superexpression (ER/HER2+), have a direct relationship between histological grade and a higher HER expression (Gama et al., 2008). In a study with humans, Steinman (2007) and colleagues verified that the positivities for HER2 expression in low-grade DCIS and highgrade DCIS were $9 \%$ and $54 \%$ of the tumors analyzed, respectively. In dogs, two thirds of high-grade DCIS had positivity for HER2 (Antuofermo et al., 2007). In the present series, HER-2 expression does not differ from that described in other studies, demonstrating the relationship with malignancy, high histological grade and suggesting a role in canine mammary carcinogenesis.

There is no ligand known to date which is specific for HER2. It is known that one of the possible ways to activate it is by forming heterodimers with other members of the same family of receptors. Among these members is EGFR, which has a specific ligand (EGF), but is also activated when in conformation with the heterodimer. HER2 preferably forms heterodimers with EGFR. This formation is more stable when compared with HER2 homodimers, although it was still less stable than EGFR. EGFR-HER2 heterodimer has a slower degradation when compared with homodimers, and the amount of HER 2 receptors activated in this conformation is larger when compared with the amount found in HER2 homodimers (Shankaran et al., 2008). The positive correlation observed in high-grade DCIS in the present study allows us to infer that there may be a link between the EGFR expression and the HER2 overexpression, thus with a worse tumor prognosis. Similar results are described in human literature (Digiovanna et al., 2005).

Bertagnolli et al., (2011) evaluated the EGFR and HER2 expression in invasive and noninvasive canine mammary carcinomas, but no study was performed to analyze the correlation of the co-expression of these receptors. Determining this co-expression is important to make an appropriate choice for the therapeutic approach to be implemented, thus choosing drugs targeted to block both receptors to make the response more effective (Kong et al., 2008). Apparently, there is no evidence of co-expression of these proteins in DCOS, as can be seen in our results.

Steinman et al., (2007) carried out a study in humans and verified that $2 \%$ of low-grade DCIS were positive for EGFR, whereas the positivity for this receptor in high-grade DCIS was $7 \%$. Our results are similar to results found by Gama et al., (2009), evaluating the malignancy of the DICS and invasive carcinomas.

The role of EGFR and HER2 proteins in neoplastic progression requires further study. The study of these two markers in canine mammary tumors should apparently be evaluated together when aiming to determine the prognostic relationship which exists in the expression of growth factor receptors. Different from what is seen in humans, the loss of EGFR and HER2 expression was found when the histological grade of the carcinomas evaluated increased, that is, high-grade ductal carcinomas in situ tend to lose the expression of these oncoproteins.

Results have led us to reflect on the theories of neoplastic progression, making us reflect more directly on the "theory of the parallel disease", where low-grade DCIS would progress to lowgrade invasive carcinoma. This theory justifies the fact that there is no increase in the expression of HER2 and EGFR when comparing low-grade and high-grade DCIS. However, nothing can be stated on this theory until more detailed studies are carried out, such as the analysis of hormone receptors (ER and $\mathrm{PR}$ ) and cell proliferation markers (Ki-67 and MIB).

\section{ACKNOWLEDGEMENTS}

The authors thank the National Council of Scientific and Technological Development (CNPq; Brazil), the Research Support Foundation of the State of Minas Gerais (FAPEMIG; Brazil) and the Federal University of Minas Gerais (PRPq - UFMG) for financial support.

\section{REFERENCES}

ANTUOFERMO, E.; MILLER, M.A.; PIRINO, S. et al. Spontaneous mammary intraepithelial lesions in dogs--a model of breast cancer. Cancer Epidemiol. Biomarkers Prev., v.16, p.2247-2256, 2007. 
BERTAGNOLLI, A.C.; FERREIRA, E.; DIAS, E.J.; CASSALI, G.D. Canine mammary mixed tumours: immunohistochemical expressions of EGFR and HER-2. Aust. Vet. J., v.89, p.312-317, 2011.

BHARGAVA, R.; GERALD, W.L.; LI, A.R. et al. EGFR gene amplification in breast cancer: correlation with epidermal growth factor receptor mRNA and protein expression and HER-2 status and absence of EGFR-activating mutations. Mod. Pathol., v.18, p.1027-1033, 2005.

DABBS, D.J.; CARTER G.; FUDGE, M. et al. Molecular alterations in columnar cell lesions of the breast. Mod. Pathol., v.19, p.344-349, 2006.

DIGIOVANNA, M.P.; STERN, D.F.; EDGERTON, S.M. et al. Relationship of Epidermal Growth Factor Receptor Expression to ErbB-2 Signaling Activity and Prognosis in Breast Cancer Patients. J. clin. Oncol., v.23, p.1152-1160, 2005.

FERREIRA, E.; GOBBI, H.; SARAIVA, B.; CASSALI, G.D. Columnar cell lesions of the canine mammary gland: patholical features and immunophenotypic analysis. BMC Cancer, v.10, p.61, 2010 .

GAMA, A.; ALVES, A.; SCHMITT, F. Identification of molecular phenotypes in canine mammary carcinomas with clinical implications: application of the human classification. Virchows Arch., v.453, p.123-132, 2008.

GAMA, A.; GÄRTNER, F.; ALVES, A.; SCHMITT, F. Immunohistochemical expression of Epidermal Growth Factor Receptor (EGFR) in canine mammary tissues. Res. Vet. Sci., v.87, p.432-437, 2009.

KONG, A.; CALLEJA, V.; LEBOUCHER, P. et al. HER2 oncogenic function escapes EGFR tyrosine kinase inhibitors via activation of alternative HER receptors in breast cancer cells. PLoS One, v.3, p.e2881, 2008.

KROGERUS, L.A.; LEIVONEN, M.; HÄSTÖ, A.L. Expression patterns of biologic markers in small breast cancers and preneoplastic breast lesions. Breast, v.9, p.281-285, 2000.

LEONARD, G.D.; SWAIN, M.S. Ductal carcinoma in situ, complexities and Challenges. J. Natl. Cancer Inst., v.96, p.906-920, 2004.

OWENS, M.A.; HORTEN, B.C.; DA SILVA, M.M. HER-2 amplification ratios by fluorescence in situ hybridization and correlation with immunohistochemistry in a cohort of 6556 breast cancer tissues. Clin. Breast Cancer, v.5, p.63-69, 2004.
ROSEN, P.P. Rosen's Breast Pathology. 3.ed. Philadelphia. Lippincott Willians \& Wilkins, 2009. p.318-319

SHANKARAN, H.; ZANG, Y.; OPRESKO, L.; RESAT, H. Quantifying the effects of co-expressing EGFR-HER2 on HER activation and trafficking. Biochem Biophys Res. Commun, v.371, p.220-224, 2008.

SLAMON, D.J.; CLARK, G.M.; WONG, S.G. et al. Human breast cancer: Correlation of relapse and survival with amplification of the HER-2/neu oncogene. Science, v.235, p.177-182, 1987.

STEINMAN, S.; WANG, J.; BOURNE, P. et al. Expression of Cytokeratin Markers, ER-alpha, PR, HER-2/neu, and EGFR in Pure Ductal Carcinoma In Situ (DCIS) and DCIS with Co-existing Invasive Ductal Carcinoma (IDC) of the Breast. Ann. Clin. Lab. Sci., v.37, p.127-134, 2007.

STOLL, B.A. Premalignant Breast Lesions: Role for Biological Markers in Predicting Progression to Cancer. Eur. J. Cancer, v.35, p.693-697, 1999.

TSUTSUI, S.; OHNO, S.; MURAKAMI, S. et al. Prognostic value of epidermal growth factor receptor (EGFR) and its relationship to the estrogen receptor status in 1029 patients with breast cancer. Breast Cancer Res Treat., v.71, p.67-75, 2002.

VOGEL C.L.; COBLEIGH, M.A.; TRIPATHY, D. et $a l$. Efficacy and safety of trastuzumab as a single agent in first-line treatment of HER-2-overexpressing metastatic breast cancer. J. Clin. Oncol., v.20, p.719726, 2002

WARNBERG, F.; NORDGREN, H.; BERGKVIST, L.; HOLMBERG, L. Tumour markers in breast carcinoma correlate with grade rather than with invasiveness. Br. J. Cancer, v.85, p.869-874, 2001.

WOLFF, A.C.; HAMMOND, M.E.; SCHWARTZ, J.N. et al. American Society of Clinical Oncology/College of American Pathologists Guideline Recommendations for Human Epidermal Growth Factor Receptor 2 Testing in Breast Cancer. Arch. Pathol. Lab. Med., v.131, p.18-43, 2007.

YAZIJI, H.; GOLDSTEIN, L.C.; BARRY, T.S. et al. HER-2 testing in breast cancer using parallel tissuebased methods. JAMA, v.291, p.1972-1977, 2004.

OWENS, M.A.; HORTEN, B.C.; DA SILVA, M.M. HER-2 amplification ratios by fluorescence in situ hybridization and correlation with immunohistochemistry in a cohort of 6556 breast cancer tissues. Clin. Breast Cancer, v.5, p.63-69, 2004. 